\title{
АНАЛІТИЧНІ ПОЛОЖЕННЯ ВПЛИВУ ПОВНОТИ ТЕХНІЧНОГО КОНТРОЛЮ НА БЕЗВІДМОВНІСТЬ САМОХІДНИХ ОБПРИСКУВАЧІВ
}

\author{
Любченко Ірина Сергіївна \\ аспірантка \\ Національний університет біоресусросів і природокористування України \\ ORCID: 0000-0001-5259-1760 \\ e-mail: lub4enko.ira@gmail.com
}

Роговський Іван Леонідович кандидат технічних наук, старший науковий співробітник Національний університет біоресусросів і природокористування України ORCID: 0000-0002-6957-1616 e-mail: rogovskii@nubip.edu.ua

В статті обговорюються питання впливу на показники безвідмоності самохідних обприскувачів систем параметрів вбудованого технічного контролю, таких як повнота і глибина технічного контролю.

Розроблено аналітичні моделі деяких типових структур безвідмовності самохідних обприскувачів, в яких враховуються характеристики технічного контролю за працездатністю елементів.

Представлена графрічна інтперпретація залежності показників безвідмовності самохідних обприскувачів від повноти технічного контролю. Підтверджено існування впливу повноти технічного контролю на показники безвідмовності структур.

Розглянутий підхід із подібним аналізом дозволяє обгрунтовано висувати вимоги до характеристик систем технічного контролю самохідних обприскувачів.

Ключові слова: безвідмовність, обприскувач, ймовірність, контроль, параметр, елемент, працездатність.

DOI: https://doi.org/10.32845/msnau.2021.1.3

Постановка проблеми. Пошукові наукові роботи 3 дослідження безвідмовності складних технічних систем, як правило, починаються зі структурно-функціонального якісного та попереднього кількісного аналізу, основними складовими якого $є$ аналіз видів відмов та їх наслідків та аналіз контролепридатності [1].

Основними показниками контролепридатності самохідних обприскувачів, регламентованими нормативною документацією [2, 3], зокрема зарубіжною [4], є повнота і глибина технічного контролю [5].

Повнота технічного контролю характеризує частку відмов самохідних обприскувачів, які виявляються під час технічного контролю працездатності [6]. У випадку якість технічного контролю самохідних обприскувачів визначається переліком модулів, відмови яких виявляються технічним контролем [7]. Тому однією з характеристик повноти технічного контролю самохідних обприскувачів може бути відношення числа контрольованих елементів до загального числа елементів об'єкта технічного контролю, що розглядається (наприклад, у відсотках) [8]. Однак для спільного моделювання безвідмовної поведінки самохідних обприскувачів та засобів технічного контролю бажано задавати повноту контролю як певний ймовірнісний показник або як відношення показників, характеристик безвідмовності (відмови) контрольованих елементів до всіх елементів. Доцільність такого завдання пояснюється тим, що при моделюванні безвідмовної поведінки аналізованого самохідного обприскувача - відмови та приховані відмови, що виявляються технічним контролем [9]. Повноту технічного контролю у разі можна визначити як умовну ймовірністю контрольованої відмови самохідного обприскувача, за умови, що відмова відбулася. I за деяких припущень [1], імовірнісний показник повноти технічного контролю самохідного обприскувача має вигляд:

$$
\eta=\frac{\sum_{j \epsilon K} \lambda_{j}}{\sum_{i=1}^{n} \lambda_{i}}
$$

де $\eta$ - повнота технічного контроля самохідного обприс,кувача; $n$ - кількість елементів самохідного обприскувача, які регламентовані технічним контролем; $\lambda_{i}-$ інтенсивність відмови i-го елемента самохідного обприскувача; $K$ загальна кількість елементів самохідного обприскувача; $\lambda_{j}-$ інтенсивність відмови ј-го елемента самохідного обприскувача.

Глибина технічного контролю характеризує роздільна здатність засобів контролю [10]. Поняття цієї властивості різноманітніше, ніж повноти технічного контролю. Наприклад, можна розуміти глибину технічного контролю деякої системи самохідних обприскувачів як глибину пошуку несправного компонента в ієрархії компонентів структури системи: агрегат, система, підсистема, модуль, елемент [11]. У цьому роботі глибина визначатиметься через типові елементи заміни; у низці зарубіжних нормативних матеріалів, особливо в авіації, такі елементи називають LRU - Line Replaceable Unit [12]. Якщо, при виникненні контрольованої відмови самохідного обприскувача, технічний контроль вказує на деяку підмножину елементів, які можливо відмовили, ці елементи або всі знімаються, в тому числі і не відмовили, і замінюються на працездатні, або всі контролюються [13]. За аналогією з повнотою глибину технічного контролю також можна розуміти як частку загальної кількості елементів самохідного обприскувача, контрольованих до одного типового елемента заміни, двох типових елементів заміни, трьох типових елементом заміни [14]. Таким чином, глибина контролю може бути представлена рядом розподілу.

Вісник Сумського національного аграрного університету 
Складові цього ряду - стаціонарні можливості зняття одного, двох, ..., n типових елементів заміни (де $\mathrm{n}$ - число елементів самохідного обприскувача, як об'єкта технічного контролю), за умови виникнення однієї відмови [15]. Якщо ці ймовірності виражені через відношення кількості елементів відповідних підмножин типових елементів заміни до загальної кількості контрольованих типових елементів заміни (наприклад, у відсотках), то така характеристика є якісною, у тому сенсі, що вона не пов'язана з моделлю комплексу «об'єкт контролю - засоби контролю» [16]. 3 погляду надійнісного аналізу глибина технічного контролю впливає на показники ремонтопридатності, зокрема, середній час відновлення працездатності, на комплексні показники, наприклад, коефіцієнт готовності, і навіть на число запасних частин [17]. Для формування моделей потоків відновлення самохідного обприскувача глибина технічного контролю може визначатися аналогічно повноті через відносини сумарних інтенсивностей відмов самохідного обприскувача для кожного члена зазначеного ряду розподілу за кількістю типових елементів заміни, що знімаються:

$$
\gamma_{k}=\frac{\sum_{i \epsilon G_{k}} \lambda_{i}}{\sum_{j \in K} \lambda_{j}}, \quad G_{i} \widehat{\imath \neq \jmath} G_{j}=\emptyset, \quad \sum_{k \in K} \gamma_{k}=1
$$

де $\gamma_{k}$ - характеристика глибини контролю для $\mathrm{k}$ елементів самохідного обприскувача, що контролюються; $G_{k}-$ підмножина контрольованих елементів, при відмові будьякого з яких перевіряється $\mathrm{k}$ елементів самохідного обприскувача; $K$ - підмножина контрольованих елементів.

3 погляду аналізу глибина технічного контролю самохідного обприскувача впливає на показники ремонтопридатності самої самохідної сільськогосподарської машини [18]. Так, середній час відновлення працездатності зростає, якщо складова $\gamma_{1}$ зменшується, оскільки зняття та перевірка більшої кількості елементів самохідного обприскувача потребує більшого часу на усунення відмови [19]. Як наслідок цього характеристики глибини впливають на комплексні показники надійності самого самохідного обприскувача, наприклад, коесріцієнт готовності [20]. Впливає також глибина технічного контролю на кількість запасних частин.

Нерідко приймається як очевидне, що технічний контроль працездатності елементів самохідного обприскувача і його систем дозволяє підвищити показники надійності [4]. Тут автори під показниками надійності розуміються як класичні показники надійності, так і показники ймовірності технічної ефективності, безпеки, що залежать від надійності. Проте такі висновки менш однозначні: необхідно обговорити більш детально питання впливу показників надійності і засобів контролю працездатності [11].

Показники готовності самохідного обприскувача можуть покращуватись, якщо технічний контроль дозволяє скоротити час перебування самохідного обприскувача у непрацездатному стані при відновленні відмов [2]. Причому коефіцієнт готовності тим більше, чим глибша повнота технічного контролю і чим більш точно глибина технічного контролю дозволяє виявляти елемент самохідного обприскувача, що відмовив [9].

Для самохідного обприскувача, тобто складної технічної системи багаторазового застосування, саме до цього класу систем відносяться як системи, так і самохідний обприскувач загалом [17]. Основним з показників надійності $є$ коефіцієнт оперативної готовності [1]. Коефіцієнт оперативної готовновті $k_{o g}\left(t_{i}, \tau_{o g}\right)$ - можливість знаходження самохідного обприскувача у довільний час $t_{i}$ у працездатному стані і безвідмовної роботи в інтервалі оперативного часу $\tau_{\text {og }}$. Можна записати вираз для $k_{o g}\left(t_{i}, \tau_{o g}\right)$ :

$$
k_{o g}\left(t_{i}, \tau_{o g}\right)=\sum_{J \in S_{p r}} k_{J}\left(t_{i}\right) \cdot P_{j}\left(t_{i}, t_{i}+\tau_{o g}\right),
$$

де $k_{J}\left(t_{i}\right)$ - ймовірність перебування самохідного обприскувача в момент $t_{i}$ у J-ум стані; $P_{j}\left(t_{i}, t_{i}+\tau_{o g}\right)$ - ймовірність безвідмовної роботи на вказаному інтервалі часу, за умови, що в момент $t_{i}$ самохідний обприскувач перебуває в стані J; $S_{p r}$ - множина працездатних станів самохідного обприскувача.

$$
k_{g}\left(t_{i}\right)=\sum_{J \in S_{p r}} k_{J}\left(t_{i}\right)
$$
скувача.

де $k_{g}\left(t_{i}\right)$ - коефіцієнт готовності самохідного обпри-

Якщо технічний контроль 100\% і всі відмови усуваються перед черговим циклом експлуатації, то $k_{g}\left(t_{i}\right)=1 \mathrm{i}$ ясно, що показник $k_{o g}\left(t_{i}, \tau_{o g}\right)$ буде вищим, ніж за відсутності відновлення перед кожним циклом застосування самохідного обприскувача за призначенням.

Таким чином, технічний контроль самохідного обприскувача дозволяє у ряді випадків підвищити безвідмовність самої машини. Але оскільки сама система технічного контролю $є$ джерелом додаткових відмов, то аналіз надійності, особливо безвідмовності, необхідно проводити при включенні в надійну модель, поряд з функціональним обладнанням, також технічні засоби технічного контролю. Модель має відбивати як позитивний ефект, і витрати під час запровадження технічного контролю [21]. Більше того, технічний контроль самохідного обприскувача лише тоді дає помітний есект, коли обірунтовано призначається технічне обслуговування. При технічному обслуговуванні додатково можуть виявлятися відмови, які не виявляються вбудованими (штатними) засобами технічногоконтролю (приховані відмови).Необхідно відзначити, що моделі надійності з урахуванням неповноти та відмов контролю, особливостей функціонування та відновлення можуть бути досить нетривіальними [22]. Як правило, для обліку таких факторів застосовувати необхідно складніший клас формування моделей, ніж логіко-імовірнісний, що лежить в основі класичних дерев відмов. У цій статті для аналізу буде застосовано марковське моделювання.

Мета. Провести огляд сучасних методів логіко-імовірнісного аналізу самохідних обприскувачів та застосувати марковське моделювання зі встановлення впливу технічного контролю на безвідмовність самохідних обприскувачів.

Результати досліджень. Модель нерезервованого модуля з неповнотою технічного контролю самохідного обприскувача (загальний випадок) представлено на рис.1а. При її побудові використані наступні припущення: інтенсивність відмов модуля самохідного обприскувача не залежить від 
часу (величини його напрацювання); відмова модуля самохідного обприскувача миттєво виявляється з ймовірністю $\eta$ (характеристика повноти технічного контролю) або не виявляється (з ймовірністю $1-\eta$ ) на розрахунковому інтервалі часу; відновлення працездатності модуля самохідного обприскувача проводиться тільки для модулів із виявленою відмовою; інтенсивність відновлення $\mu$ від тривалості відновлення не залежить.

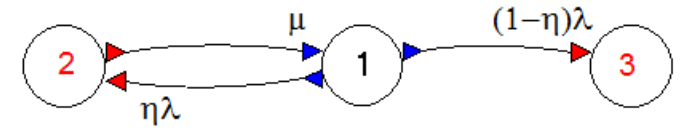

a)

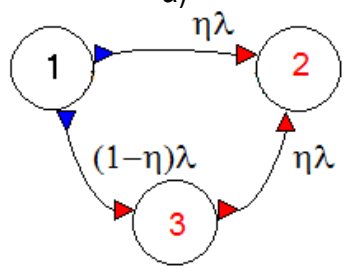

б)

Рис.1. Марковські моделі нерезервованого модуля із неповним технічним контролем самохідного обприскувача.

Інтенсивності переходів між станами марковської графр-моделі визначаються такими співвідношеннями: $\lambda_{k}=\eta \cdot \lambda$ - інтенсивність виявленого засобами технічного контролю відмови; $\lambda_{n k}=(1-\eta) \cdot \lambda-$ інтенсивність невиявленого технічним контролем відмови.

Номери станів моделі рис.1а відповідають наступним станам працездатності/непрацездатності модуля самохідного обприскувача: 1 - стан справності (працездатний); 2 стан непрацездатності після виникнення відмови, виявленої засобами технічного контролю (допускає відновлення працездатності); 3 - стан непрацездатності після виникнення відмови, який засобами технічного контролю не виявлено (поглинаючий стан марковського процесу).

Ця модель може бути підкоригована для відсутності відновлення у процесі застосування самохідного обприскувача за призначенням у таких припущеннях

- відновлення відмов може проводитись лише після закінчення застосування самохідного обприскувача за призначенням;

- відновлення проводиться, якщо має місце контрольована відмова, причому якщо до контрольованої відмови була неконтрольована відмова, то відновлюються всі відмови;

- якщо має місце лише неконтрольована відмова, вона виявляється і усувається лише за планового технічного обслуговування, тобто. у наступні після неконтрольованої відмови періоди застосування самохідного обприскувача за призначенням до планового технічного обслуговування відповідний модуль непрацездатний.

Ці припущення характерні для всіх вузлів, механізмів, елементів самохідного обприскувача, як нерезервованих систем, зокрема, функціональних систем, причому таким чином може бути змодельований і нерезервований канал. Модель представлена на рис. 1б. Тут (рис. 1б) стан 1 - працездатний стан модуля (каналу) самохідного обприскувача; стан 2 стан, що відповідає контрольованій відмові безвідносно до того чи була неконтрольована відмова самохідного обприскувача; стан 3 - стан неконтрольованої відмови самохідного обприскувача. Відобразити одним станом можна, так як це непрацездатний стан, що відновлюється за вищезазначеним припущенням при будь-якій комбінації відмов самохідного обприскувача, причому час відновлення не враховується.

На цій моделі (рис. 1б) зручно показати залежність коесріцієнта оперативної готовності самохідного обприскувача від часу. Коефріцієнт оперативної готовності самохідного обприскувача - основний показник надійності для систем багаторазового циклічного застосування, якими і є системи самохідного обприскувача. На оцінку цього показника впливають режим експлуатації самохідного обприскувача, характеристики процесу відновлення відмов та регламент технічного обслуговування. Коефіцієнт оперативної готовності $k_{o g}(t, \tau)$ визначається як ймовірність знаходження системи у довільний момент часу $t$ у працездатному стані та подальшого безвідмовного функціонування на заданому інтервалі часу $\tau$.

$k_{o g}(t, \tau)$ враховує безвідмовність в період експлуатації самохідного обприскувача, можливість відновлення у перервах між денної експлаутації відмов, що з'явилися і виявлених у процесі експлуатації, можливість перевірки працездатності (у тому числі, виявлення прихованих відмов) та відновлення виявлених відмов при плановому технічному обслуговуванні. Цей показник дозволяє комплексно врахувати всі перелічені фактори, у тому числі характеристики контролепридатності - повноту технічного контролю, ймовірності відмов щодо функції контролю типу хибних спрацьовувань та неспрацьовувань елементів самохідного обприскувача.

Марковському графу на рис. 16 відповідає система диференціальних рівнянь:

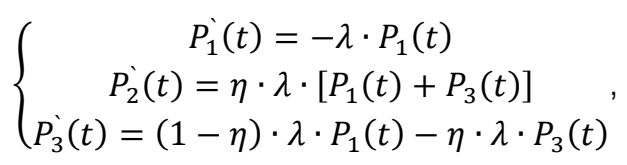

Рішення системи (8) має наступний вид:

$$
\left\{\begin{array}{c}
P_{1}(t)=C_{1} \cdot e^{(-\lambda \cdot t)} \\
P_{2}(t)=1-C_{3} \cdot e^{(-\eta \cdot \lambda \cdot t)} \\
P_{3}(t)=C_{3} \cdot e^{(-\eta \cdot \lambda \cdot t)}-C_{1} \cdot e^{(-\lambda \cdot t)}
\end{array},\right.
$$

Для розглянутої моделі (6) коефіцієнт оперативної готовності, без вархування часу відновлення самохідного обприскувача після закінчення періоду експлуатації за призначенням, може бути записано у наступному виді:

$$
k_{o g}\left(t_{j}, t_{j+1}\right)=k_{g}\left(t_{j}\right) \cdot P_{b r}\left(t_{j}, t_{j+1}\right),
$$

де $k_{g}\left(t_{j}\right)$ - коефіцієнт готовності в момент часу $t_{j}$ початку $j+1$-го періоду експлуатації самохідного обприскувача після проведення профілактичного технічного обслуговування. Автори вважають, що на профрілактичному технічному обслуговуванні відновлюються всі відмови, тобто функціонування системи починається з повністю справного стану самохідного обприскувача. $P_{b r}\left(t_{j}, t_{j+1}\right)$ - ймовірність безвідмоної на інтервалі часу $t_{j}$ саме $j+1$-го періоду експлуа- 
тації самохідного обприскувача після проведення профілактичного технічного обслуговування; $j=0,1,2, \ldots, \frac{T_{T O}}{t_{e}} \cdot t_{e}-$ максимальне сезонне навантаження самохідного обприскувача.

3 урахуванням зроблених припущень (зокрема, що у проміжку між профілактичним технічним обслуговувань відновлюються лише контрольовані відмови) можна записати:

$$
\begin{gathered}
\left\{\begin{array}{r}
P_{1}\left(t_{j}, t_{j+1}\right)=C_{1}\left(t_{j}\right) \cdot e^{\left(-\lambda \cdot\left\{t_{j+1}-t_{j}\right\}\right)}= \\
=k_{o g}\left(t_{j}, t_{j+1}\right) \\
P_{2}\left(t_{j}, t_{j+1}\right)=1-C_{3} \cdot e^{\left(-\eta \cdot \lambda \cdot\left\{t_{j+1}-t_{j}\right\}\right)}, \\
P_{3}\left(t_{j}, t_{j+1}\right)=C_{3} \cdot e^{\left(-\eta \cdot \lambda \cdot\left\{t_{j+1}-t_{j}\right\}\right)}- \\
-C_{1}\left(t_{j}\right) \cdot e^{\left(-\lambda \cdot\left(t_{j}\right)\right)}
\end{array}\right. \\
\text { де } C_{1}\left(t_{j}\right)=P_{1}\left(t_{j}\right)+P_{2}\left(t_{j}\right) ; C_{3}=1, \text { aбо } \\
k_{g}\left(t_{j}\right)=P_{1}\left(t_{j}\right)+P_{2}\left(t_{j}\right) \\
P_{b r}\left(t_{j}, t_{j+1}\right)=P_{1}\left(t_{j}\right) \cdot e^{\left(-\lambda \cdot\left\{t_{j+1}-t_{j}\right\}\right)}
\end{gathered}
$$

За даними виразами (9) і (10) побудовані залежності коефіцієнта оперативної готовності самохідного обприскувача до різних значень повноти контролю $\eta$, представлені на рис. 2. Залежності побудовані на інтервалі часу між технічними обслуговуваннями в припущенні повного відновлення всіх відмов при технічному обслуговуванні. На міжпрофрілактичному інтервалі відновлюються лише виявлені відмови. Після проведення технічного обслуговування процес повторюється.
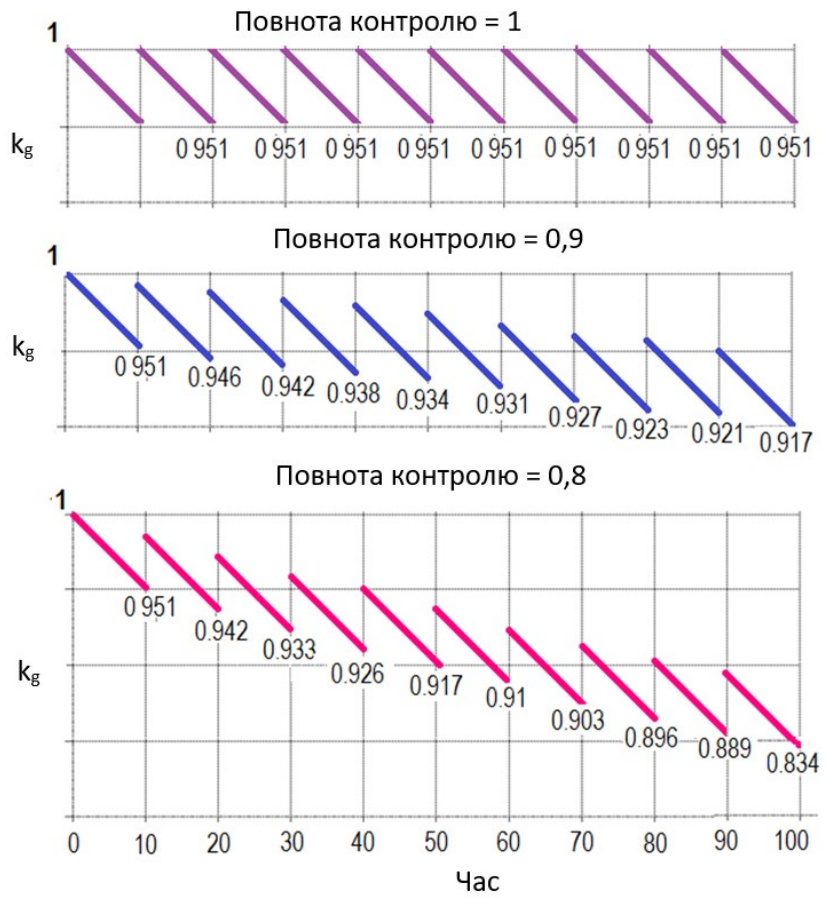

Рис.2. Оперативна готовність самохідного обприскувача за різних значень повноти технічного контролю.
При неабсолютній повноті технічного контролю самохідного обприскувача такий аналіз систем дозволяє, зокрема, обґрунтовано призначати величину міжпрофілактичного інтервалу, виходячи з вимог щодо безвідмоності для періоду застосування за призначенням, та обґрунтовувати вимоги до повноти технічного контролю.

Різні показники безвідмоності характеризують окремі властивості надійності самохідного обприскувача, тому під час аналізу систем доцільно визначати певний спектр основних показників надійності самохідного обприскувача, що дозволяють отримувати всебічну оцінку надійних властивостей аналізованої системи самохідного обприскувача [5]. Для інших моделей систем з урахуванням коштів та алгоритмів технічного контролю (наведених нижче) будуть, в основному, визначатися показники безвідмовності.

Класична мажоритарна структура із вибором 2/3. Три однакові модулі з'єднані за схемою мажоритарного резервування. У кожному модулі сума інтенсивностей контрольованої та відновлюваної відмови дорівнює $\lambda_{k}=\eta \cdot \lambda$, а неконтрольованої прихованої відмови $\lambda_{n k}=(1-\eta) \cdot \lambda$, де $\lambda-$ сумарна інтенсивність відмови модуля (рис. За). У разі виникнення тільки неконтрольованої відмови він залишається прихованим і відновлення не проводиться. Якщо в каналі виникає контрольована відмова, то модуль повністю відновлюється, навіть якщо там була вже неконтрольована відмова. Це відома, можна сказати класична, схема надійної поведінки мажоритарного резервування, за наявності тільки вбудованого технічного контролю в кожному модулі самохідного обприскувача. Марковська модель наведена на рис. $3 б$.

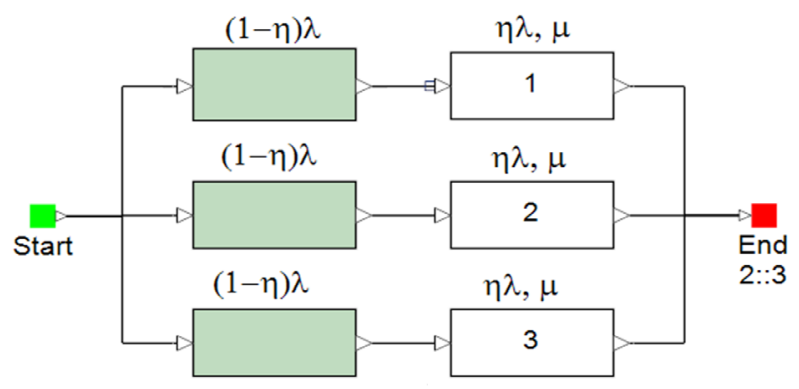

неконтрольована частина

контрольована частина

a)

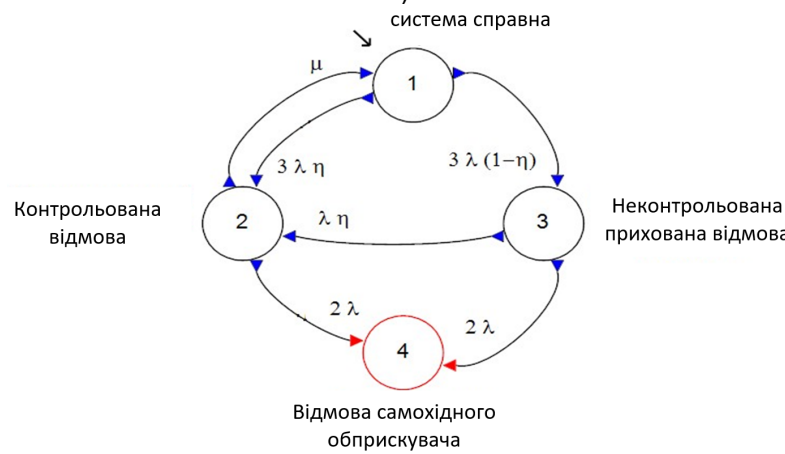

б)

Рис.3. Мажоритарне резервування за неповного технічного контролю (а) і марковський граф надійності мажоритарної схеми (б)

На рис. 4 представлений графрік, на якому по осі абс- 
цис відкладено відношення середнього напрацювання до відмови мажоритарної схеми з відновленням елементів самохідного обприскувача, відмови яких розпізнаються контролем, до середнього напрацювання до відмови модуля; по осі абсцис - повнота контролю. А на рис. 5 - відношення ймовірності відмови мажоритарної схеми за різної повноти технічного контролю до ймовірності відмови схеми при повноті контролю $\eta=1$. На графріках наведено по дві криві, побудовані для значень параметра $\rho$ (відношення середнього часу до відмови одного елемента (одного каналу) до середнього часу відновлення), що дорівнює 100 і 1000.

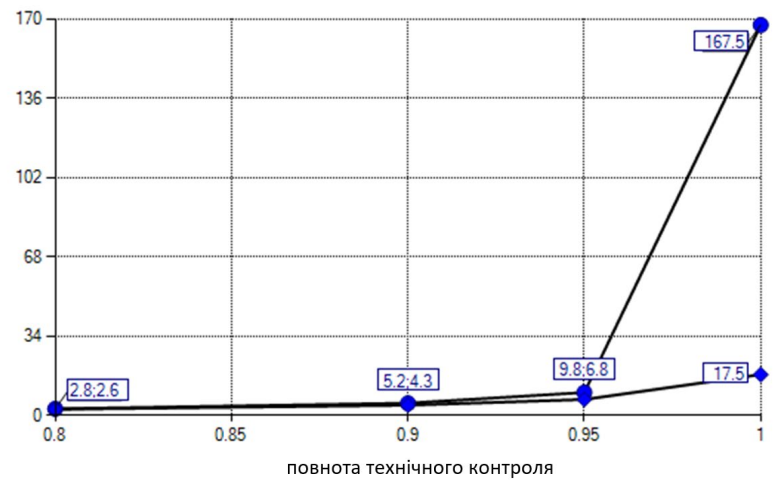

$\rightarrow p=1000 \rightarrow p=100$

Рис.4. Залежність середнього напрацювання до відмови від повноти технічного контролю.

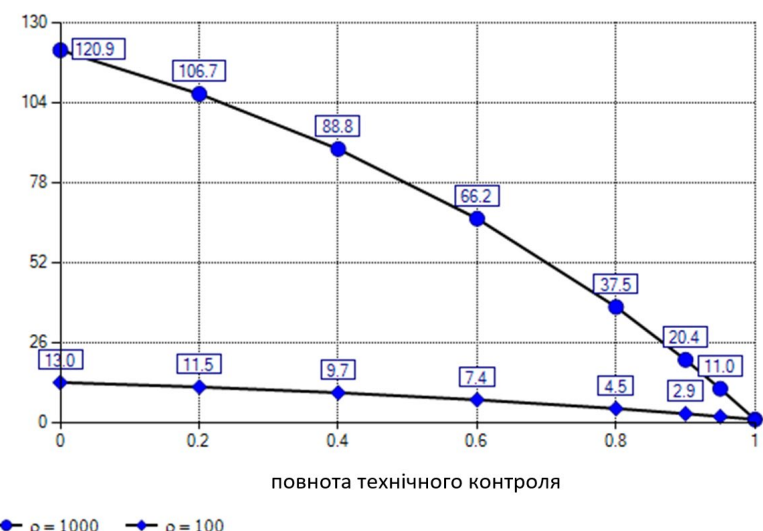

Рис.5. Залежність ймовірності відмовитися від повноти технічного контролю.

3 розгляду графіка (рис. 6) видно, що повнота контролює фактором, що покращує показники безвідмовності резервованих структур, що складаються з елементів, що відновлюються. Причому, лише за досить високих значеннях повноти контролю $(\eta>0,95)$, значення такого показника як середній наробіток мажоритарної структури суттєво збільшується. Імовірність відмови із зростанням повноти технічного контролю зменшується поступово.

Дублювання модулів за схемою 2 із 2 з порівнянням та з переходом на схему 1 із 2 при відмові одного з модулів. Інакше кажучи, виникнення несправності у раніше справній дубльованій ланці, тобто, відмова одного з модулів виявляється з ймовірністю 1 (за умови працездатності елемента порівняння). Наслідки відмови модуля та характер процесу відновлення залежить від виду відмови:
- у разі виникнення невиявленого засобами (само)контролю відмови модуля настає відмова (виявлений пристроєм порівняння), після чого починається процес відновлення працездатності;

- при виникненні виявленого засобами (само)контролю відмови модуля, працездатність забезпечується другим (справним) модулем, а працездатність модуля, що відмовила, відновлюється.

Марковська модель дубльованої ланки з порівнянням і з переходом на схему 1 із 2 представлена на рис. 6 .

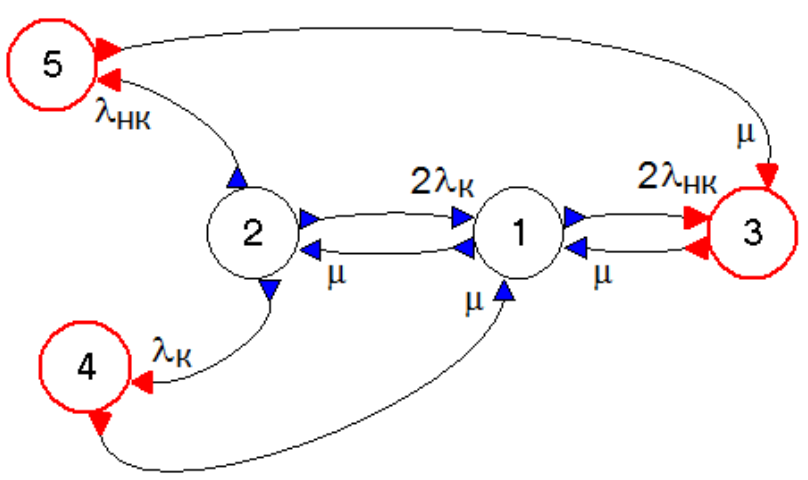

Рис.6. Дублювання модулів за схемою 2 із 2 з порівнянням і з переходом на схему 1 із 2.

Номери станів моделі рис. 6 відповідають наступним станам працездатності ланки:

1 - стан справності (працездатний);

2 - стан працездатності після відмови модуля, виявленого засобами технічного контролю (допускає відновлення працездатності модуля);

3 - стан непрацездатності після виникнення відмови модуля, виявленого пристроєм порівняння (допускає відновлення працездатності модуля та самохідного обприскувача в цілому);

4 - стан непрацездатності після виникнення відмови також і другого модуля, виявленого пристроєм технічного контролю (допускає відновлення працездатності модуля та самохідного обприскувача в цілому);

5 - прихована відмова після виникнення невиявленої відмови другого модуля на інтервалі часу відновлення працездатності першого модуля; завершення процесу відновлення модуля, який відмовив першим; включення першого модуля в роботу виявляє приховану відмову другого модуля (перехід з інтенсивністю $\mu$ зі стану 5 у стан 3).

Марковська модель ланки з дублюванням за схемою провідний - ведений представлена на рис. 7.

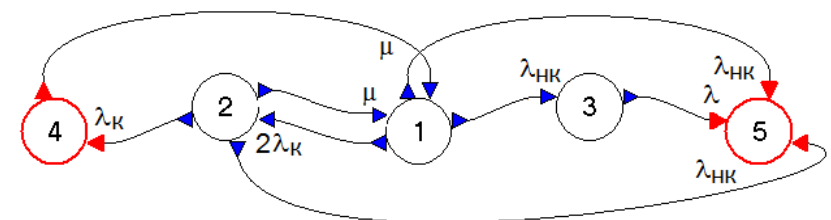

Рис.7. Дублювання за схемою провідний - ведений.

Номери станів моделі рис. 7 відповідають наступним станам працездатності/непрацездатності самохідного обприскувача:

1 - стан справності (працездатний); 
2 - стан працездатності після виникнення відмови модуля (провідного чи веденого), виявленого засобами технічного контролю (допускає відновлення працездатності модуля);

3 - стан працездатності після виникнення відмови веденого модуля, невиявленого засобами технічного контролю

4 - стан непрацездатності після виникнення відмови також і другого модуля, виявленого засобами технічного контролю (допускає відновлення працездатності модуля та самохідного обприскувача загалом);

5 - стан непрацездатності; прихована відмова ланки після виникнення:

- першої невиявленої відмови провідного модуля (перехід зі стану 1);

- другої невиявленої відмови модуля на інтервалі часу відновлення працездатності модуля, який відмовив першим (перехід зі стану 2);

- відмови провідного модуля за наявності прихованої відмови у веденого (перехід зі стану 3);

У 5 стані відновлення працездатності ланки не відбувається через невиявлення відмови.

На рис. 8, рис. 9 наведено залежність ймовірності безвідмовної роботи самохідного обприскувача (сума ймовірностей станів $1,2,3)$ та ймовірності небезпечної відмови (ймовірність стану 5) від часу при різних значеннях повноти технічного контролю.

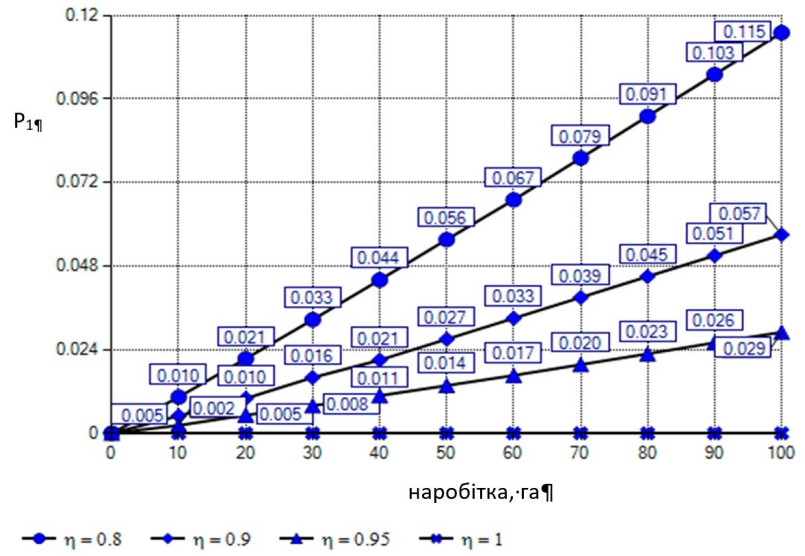

Рис.8. Залежність ймовірності відмови від наробітку при різних значеннях повноти технічного контролю.

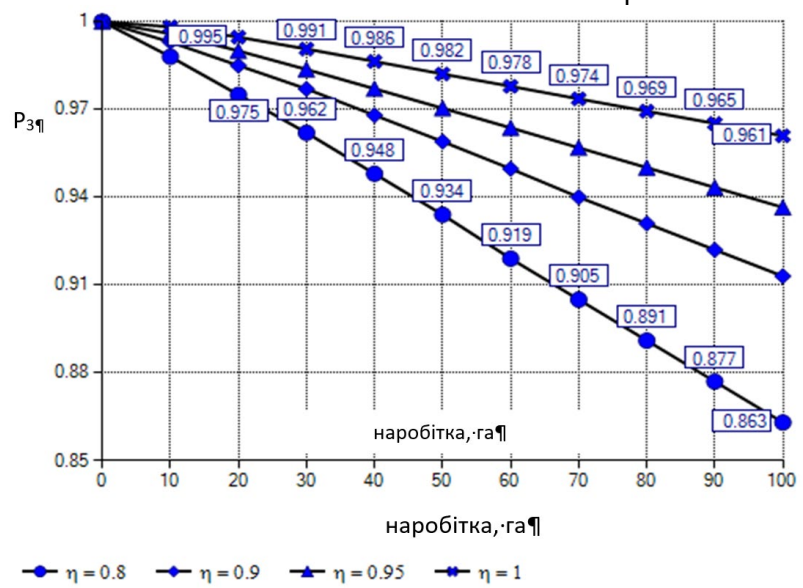

Рис.9. Залежність ймовірності безвідмовної роботи від наробітку за різних значень повноти технічного контролю.
На рис. 10 представлена залежність від повноти технічного контролю значень цих показників на $t=100$ га. Повнота технічного контролю істотно впливає на показники безвідмоності самохідного обприскувача.

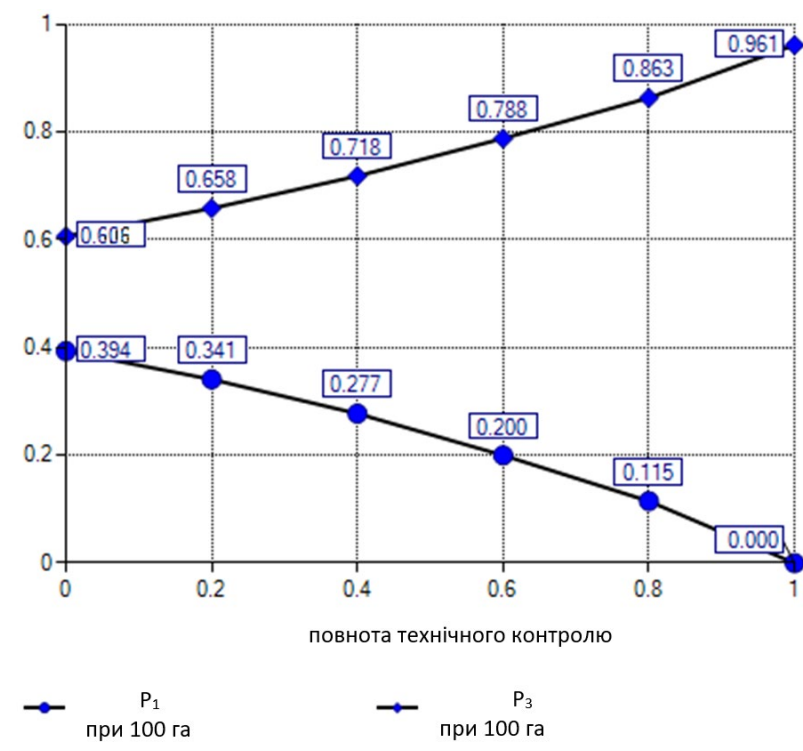

Рис.10. Залежність безвідмовності від повноти технічного контролю.

Троювання модулів за схемою 2 з 3 із порівнянням 3 метою технічного контролю. У аналізованому варіанті резервування будь-яка відмова одного з модулів завдяки порівнянню буде виявлено і, оскільки результат формується на основі мажоритарного принципу, даний стан самохідного обприскувача буде станом працездатності. На час відновлення модуля, що відмовив, обприскувач функціонуватиме за правилами дубльованої ланки з порівнянням вихідних сигналів. Марковська модель з троюванням модулів, в якій реалізовані зазначені принципи забезпечення технічного контролю та працездатності, представлена на рис. 11.

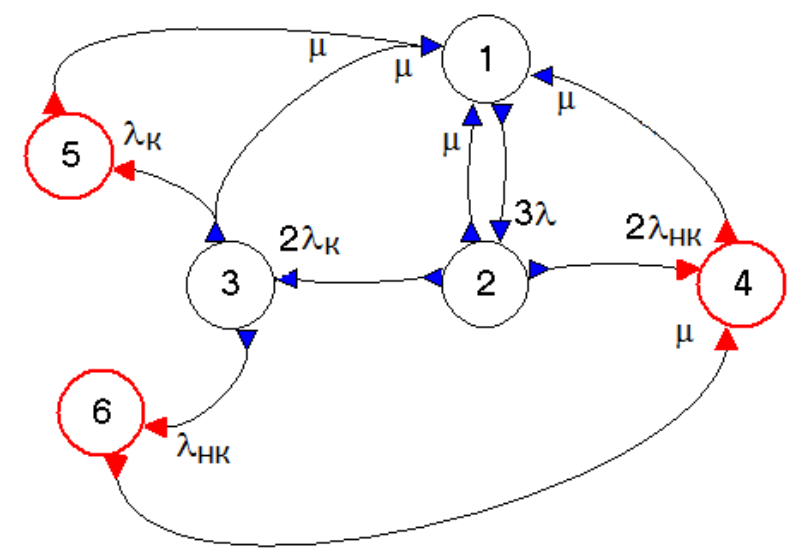

Рис.11. Троювання за схемою 2 з 3 із порівнянням з метою технічного контролю самохідного обприскувача.

Номери станів моделі рис. 11 відповідають наступним станам працездатності самохідного обприскувача:

1 - стан справності (працездатний);

2 - стан працездатності після відмови модуля, виявленого засобами порівняння; 
3 - стан працездатності після відмови другого модуля, виявленого засобами технічного контролю;

4, 5, 6 - стан непрацездатності після виникнення двох відмов модулів, виявлених засобами порівняння.

Усі непрацездатні стани ланки є відновлюваними.

На відміну від схем дублювання при троюванні модулів одноразова відмова будь-якого типу не призводить до відмови самохідного обприскувача.

Висновки. Модель (рис. 1б) описує залежність коесіцієнта оперативної готовності самохідного обприскувача від часу. На оцінку цього показника впливають режим експлуатації самохідного обприскувача, характеристики процесу відновлення відмов та регламент технічного обслуговування. Коефіцієнт оперативної готовності $k_{o g}(t, \tau)$ визначається як ймовірність знаходження системи у довільний момент часу $t$ у працездатному стані та подальшого безвідмовного функціонування на заданому інтервалі часу $\tau$.

$k_{o g}(t, \tau)$ враховує безвідмовність в період експлуатації самохідного обприскувача, можливість відновлення у перервах між денної експлаутації відмов, що з'явилися і виявлених у процесі експлуатації, можливість перевірки працездатності (у тому числі, виявлення прихованих відмов) та відновлення виявлених відмов при плановому технічному обслуговуванні. Цей показник дозволяє комплексно врахувати всі перелічені фрактори, у тому числі характеристики контролепридатності - повноту технічного контролю, ймовірності відмов щодо функції контролю типу хибних спрацьовувань та неспрацьовувань елементів самохідного обприскувача.

\section{Список використаної літератури:}

1. Najafi, P., Asoodar, M., Marzban, A., Hormozi, M. 2015. Reliability analysis of agricultural machinery: A case study of sugarcane chopper harvester. AgricEngInt: CIGR Journal March 17(1)1: 158-165

2. Gurcanli, E., Bilir, S., Sevim, M. 2015. Activity based risk assessment and safety cost estimation for residential building construction projects. Safety Science 80: 1-12.

3. Khamidullina, E.A., Timofeeva, S.S., Smirnov, G.I. 2017. Accidents in coal mining from perspective of risk theory. IOP Conference Series: Materials Science and Engineering 262: 012210.

4. Aven, T. 2016. Risk assessment and risk management: review of recent advances on their foundation. European Journal of Operational Research 253(1): 1-13.

5. Tyutrin, S. 2019. Improving reliability of parts of mounted mower according to monitoring results by fatigue gauges from tin foil. Engineering for rural development 18: 22-27.

6. Voinalovych, O., Hnatiuk, O., Rogovskii, I., Pokutnii, O. 2019. Probability of traumatic situations in mechanized processes in agriculture using mathematical apparatus of Markov chain method. Engineering for rural development 18: 563-569.

7. Rogovskii, I., Titova, L., Novitskii, A., Rebenko, V. 2019. Research of vibroacoustic diagnostics of fuel system of engines of combine harvesters. Engineering for rural development 18: 291-298.

8. Duan, F., Živanovi'c, R., Al-Sarawi, S., Mba, D. 2016. Induction motor parameter estimation using sparse grid optimization algorithm. IEEE Trans. Ind. Inf 12: 1453-1461.

9. Shih-Heng, T., Ming-Hsiang, S., Wen-Pei, S. 2018. Development of digital image correlation method to analyse crack variations of masonry wall. Sadhana 6: 767-779.

10. Gyansah, L., Ansah, A. 2020. Fatigue crack initiation analysis in 1060 steel. Research journal of applied sciences engineering and technology 4(2): 319-325.

11. Nykyforchyn, H., Lunarska, E., Tsyrulnyk, O. 2019. Environmentally assisted "in-bulk" steel degradation of long term service gas trunkline. Engineering Failure Analysis 17: 624-632.

12. Corinne, B., José, R. 2017. Estimating the Hurst parameter. Statistical Inference for Stochastic Processes. Springer Verlag, 10(1): 49-73.

13. Kypris, O., Nlebedim, I., Jiles, D. 2016. Measuring stress variation with depth using Barkhausen signal. Journal of Magnetism and Magnetic Materials - Science Direct 407: 377-395.

14. Erokhin, M., Pastukhov, A., Kazantsev, S. 2019. Operability assessment of drive shafts of John Deere tractors in operational parameters. Engineering for rural development 18: 28-33.

15. Xi, L., Songlin, Z. 2019. Changes in mechanical properties of vehicle components after strengthening under low-amplitude loads below the fatigue limit. Fatigue and Fracture of Engineering Materials and Structures 32(10): 847-855.

16. Rejovitzky, E., Altus, E. 2013. On single damage variable models for fatigue. International Journal of Damage Mechanics 22(2) 2: 268-284.

17. Pisarenko, G., Voinalovych, O., Rogovskii, I., Motrich, M. 2019. Probability of boundary exhaustion of resources as factor of operational safety for agricultural aggregates. Engineering for rural development 18: 291-298.

18. Sánchez-Hermosilla, J., Rincón, V., Páez, F. 2011. Field evaluation of a self-propelled sprayer and effects of the application rate on spray deposition and losses to the ground. Pest Management Science 67(8): 942-947.

19. Kalinichenko, D., Rogovskii, I. 2017. Modeling technology in centralized technical maintenance of combine harvesters. TEKA 17(3): 93-102. 12-18.

20. Zou, F., Kang, J., Xiao, M., Ji, G. 2017. Hydrostatic driving system for self-propelled sprayer. Engineering Journal 26(3):

21. Rogovskii, I. 2020. Algorithmicly determine the frequency of recovery of agricultural machinery according to degree of resource's costs. Machinery \& Energetics. Journal of Rural Production Research 11(1): 155-162.

22. Chen, Y., Mao, E., Li, W., Chen, J. 2020. Design and experiment of a high-clearance self-propelled sprayer chassis. International Journal of Agricultural and Biological Engineering 13(2): 71-80. 
Lyubchenko I. S., National University of Life and Environmental Sciences of Ukraine (Ukraine)

Rogovskii I. L., National University of Life and Environmental Sciences of Ukraine (Ukraine)

Analytical provisions of influence of completeness of technical control on faultlessness of self-propelled sprayers

The article discusses the impact of the parameters of built-in technical control, such as the completeness and depth of technical control, on the reliability of self-propelled sprayers.

Analytical models of some typical failure-free structures of self-propelled sprayers have been developed, which take into account the characteristics of technical control over the efficiency of the elements.

A graphical interpretation of the dependence of the reliability of self-propelled sprayers on the completeness of technical control is presented. The existence of the influence of completeness of technical control on the indicators of failure of structures is confirmed.

The considered approach with a similar analysis allows to reasonably make requirements to the characteristics of technical control systems of self-propelled sprayers.

Key words: faultlessness, sprayer, probability, control, parameter, element, efficiency.

Дата надходження до редакції: 16.02.2021 